\title{
Analysis of the Spatial Patterns of Pierce's Disease Incidence in the Lower San Joaquin Valley in California
}

\author{
K. M. Tubajika, E. L. Civerolo, M. A. Ciomperlik, D. A. Luvisi, and J. M. Hashim
}

First and second authors: U.S. Department of Agriculture-Agricultural Research Service (USDA-ARS), San Joaquin Valley Research Center, Parlier, CA; third author: USDA Animal and Plant Health Inspection Service (APHIS), Mission, TX; and fourth and fifth authors: University of California Cooperative and Extension, Bakersfield.

Current address of K. M. Tubajika: USDA APHIS CPHST, Otis Pest Survey, Detection and Exclusion Laboratory, Otis ANGB, MA 02542. Accepted for publication 15 June 2004.

\begin{abstract}
Tubajika, K. M., Civerolo, E. L., Ciomperlik, M. A., Luvisi, D. A., and Hashim, J. M. 2004. Analysis of the spatial patterns of Pierce's disease incidence in the lower San Joaquin Valley in California. Phytopathology 94:1136-1144.

The incidence of Pierce's disease (PD), caused by Xylella fastidiosa, was monitored in 11 naturally infested commercial vineyards to determine the presence of an X. fastidiosa vector, Homalodisca coagulata (glassy-winged sharpshooter [GWSS]), to examine the spatial patterns of the disease and elucidate possible influences of surrounding environments. Disease incidence ranged from $<1$ to $65 \%$ among vineyards in 2001. Our efforts to trap or capture potential disease vectors have indicated that the GWSS is the most likely vector. Disease incidence doubled in most vineyards during the 2002 production season. Spatial patterns of

analysis, showed strong evidence for within- and across-row aggregation of infected vines. In most fields, they were no disease gradients observed relative to GWSS source (e.g., citrus). Within fields, however, disease incidence displayed strong spatial dependence and a high degree of anisotropy, indicating strongly aggregated patterns of disease with distinct directional orientation. The within-row $\left(0^{\circ}\right)$ and across-row $\left(90^{\circ}\right)$ orientations generally were the predominant directions of increased disease incidence, consistent with vine-to-vine spread of $X$. fastidiosa. We concluded that the distribution of PD in vineyards reflected the feeding pattern of vectors carrying $X$. fastidiosa. Based on these results, effective PD management is likely to be based on practices that reduce significant insect vector populations and remove infected vines as soon as identified and on the use of resistant cultivars.
\end{abstract} symptomatic vines in 2001 and 2002, as determined by ordinary runs

Pierce's disease (PD) of grapevines (Vitis vinifera L.) is a serious constraint to wine, table, and raisin grape production in California. The disease is caused by the bacterium Xylella fastidiosa Wells et al. (43), which also causes leaf scorch symptoms in almond, plum, elm, and oak, and stunting in peach, alfalfa, and some weeds (34). Several leafhopper species transmit the bacterium (31). The incidence of PD has continued to increase in many grape-growing areas in California due to the appearance, establishment, and spread of a newly introduced vector, the glassywinged sharpshooter (GWSS), Homalodisca coagulata (Say) (3). The introduction of the GWSS has changed the epidemiology of $X$. fastidiosa diseases affecting important agronomic and horticultural crops as well as landscape ornamental and native trees in California by infesting these crops with the bacteria.

It is not clear if management strategies for PD developed in GWSS-free regions of California are suitable to manage the disease in vineyards where GWSS has established. Data from earlier studies suggest that GWSS has continued to expand in number and range in California (33). GWSS populations are widely distributed over a large number of hosts including perennial agronomic crops, ornamental plantings, and weedy species $(3,18,19$, 33,37). Previous studies by Blua et al. (3) and Perring et al. (26) showed that GWSS populations utilize citrus as their primary reproductive host, and citrus may be the predominant overwintering

Corresponding author: K. M. Tubajika

E-mail address: Kayimbi.Tubajika@aphis.usda.gov

Publication no. P-2004-0823-01R

This article is in the public domain and not copyrightable. It may be freely reprinted with customary crediting of the source. The American Phytopathological Society, 2004
Additional keyword: geostatistics. host when grapes, stone fruits, ornamental hosts, and weedy species are dormant during winter. This vector may have a great impact on grape-growing areas in the lower San Joaquin Valley due to numerous citrus orchards that support overwintering populations. GWSS has been shown to transmit $X$. fastidiosa to grape (5) with efficiency comparable to some vectors such as Draeculacephala minerva Ball (green sharpshooter) (GSS) and Carneocephala fulgida Nott (red-headed sharpshooter) (RHSS) (28) but much less than in Graphaecephala (Hordnia) atropunata (Sigmoret) (blue-green sharpshooter) BGSS (28).

$X$. fastidiosa is spread from plant-to-plant by sharpshooters and leafhoppers as they feed on xylem sap. The bacteria then multiply and spread throughout the xylem. Overt symptoms of PD are drying or scorching of leaves, extensive marginal scalding of leaf blades, premature senescence of numerous leaves, irregular zones of bark maturity, necrosis, and chlorosis of leaf margins $(2,28)$. Symptoms are more evident by middle to late summer when high temperature, low humidity, wind, and low soil water availability increase water stress (2).

In earlier studies, it was shown that the bacteria killed susceptible grapevines adjacent to permanent water sources where weed hosts of the pathogen and sharpshooter and leafhopper vectors occur concomitantly $(36,37)$. Based on these earlier findings with BGSS, GSS, and RHSS, Purcell (28) showed that PD incidence was highest near natural riparian vegetation and decreased with distance from the source (up to 120 to $150 \mathrm{~m}$ ). The observed disease gradients generally followed a pattern predicted by the power law model (15). Hewitt et al. (17) noted a steep PD incidence gradient from about $40 \%$ infection in the rows nearest alfalfa and a decrease in percentage of vines infected as the distance from the source increased. Irrigated pastures also provided 
vector sources of BGSS and RHSS from which a gradient of PD developed in vineyards $(18,27,32)$. The spatial pattern of PD vectored by the BGSS relative to vector breeding habitats suggests that the disease is spread mostly by vector coming from sources outside the vineyards, suggesting that vine-to-vine spread of PD is limited (28). However, in the Gulf Coastal Plains states, vineto-vine spread of $X$. fastidiosa may be dominant $(1,20)$. Little information is currently available on the distribution and spread of $X$. fastidiosa infections by GWSS in vineyards in the lower San Joaquin Valley in California. A more complete understanding of the spatial patterns of PD can provide useful clues to the importance of primary inoculum and mechanisms of pathogen dispersal.

The purpose of this study was to determine the presence of an $X$. fastidiosa vector, GWSS, to examine the spatial patterns of the disease, and to elucidate possible influences of surrounding environments on disease. Preliminary results of this work have been reported previously $(40,41)$.

\section{MATERIALS AND METHODS}

Field plots. Field experiments were conducted during 2001 and 2002 in the area-wide management pilot project for the control of GWSS located in the lower San Joaquin Valley in Kern County, California. Twelve fields were chosen based on their proximity to overwintering hosts of GWSS, age, grape cultivar, and previous GWSS infestation levels (Table 1). A field located $5 \mathrm{~km}$ from citrus-grape interface was used to detect background contamination and used as a control field. Spread of $X$. fastidiosa was assessed on vines in fields on 21 to 25 rows of 40 vines. Field 1 consisted of 0.79 ha in 25 rows of 40 vines of cv. Flame Seedless. Field 2 consisted of 0.54 ha in 25 rows of 40 vines of cv. Redglobe. Field 3 consisted of 0.54 ha in 21 rows of 40 vines of cv. Autumn Royal. Field 4 consisted of 0.86 ha in 25 rows of 40 vines of $\mathrm{cv}$. Redglobe. Field 5 consisted of 0.65 ha in 25 rows of 40 vines of cv. Crimson Seedless. Field 6 consisted of 0.79 ha in 25 rows of 40 vines of cv. Flame Seedless. Field 7 consisted of 0.78 ha in 25 rows of 40 vines of cv. Flame Seedless. Field 8 consisted of 0.63 ha in 25 rows of 40 vines of cv. Flame Seedless. Field 9 consisted of 0.48 ha in 25 rows of 40 vines of cv. Redglobe. Field 10 consisted of 0.65 ha in 25 rows of 40 vines of cv. Crimson Seedless. Field 11 consisted of 0.65 ha in 25 rows of 40 vines of cv. Redglobe. The control field (field 12) was bordered by citrus and consisted of 0.80 ha in 25 rows of 40 vines of cv. Redglobe. Management practices were consistent among vineyards (2). During the spring of each year, the same fields were surveyed.

Disease assessment. Fields were assessed at various times (30-day interval) each year for PD symptoms. In 2001, the assessment started on day 122 (Julian date) and ended on day 241. In 2002, disease was assessed on day 124 and ended on day 246.
The presence or absence of PD symptoms was recorded for each vine and the incidence (+/-) was confirmed by double-antibody sandwich, enzyme-linked immunosorbent assay (DAS-ELISA) (38) and immunocapture polymerase chain reaction (IC-PCR) $(24,27)$ using RST31 and RST33 primers. Incidence was expressed as the percentage of the total plants showing PD symptoms. In addition to disease incidence of vines, each vineyard block was divided into 100 contiguous quadrats. A quadrat within a vineyard block consisted of five adjacent rows of two vines each. The quadrat size varied from 3.0 by $18.0 \mathrm{~m}$ to 4.0 by $20 \mathrm{~m}$. Each vine in a vineyard block was inspected visually for PD monthly throughout the production season for stunted shoot growth, leaf scorch, and persistent petioles, a condition that occurs when the leaf blades scald and abscise, leaving only petioles attached to the shoot $(2,28)$. Disease incidence was calculated for each quadrat and the percentage of quadrats with at least one diseased vine was calculated as described previously. Vines were assigned the status of healthy or symptomatic. The position of each symptomatic vine was mapped.

Isolation and pathogen identification. To identify the presence of $X$. fastidiosa, a total of 200 leaf samples (10 leaf samples per vine with symptoms $\times 10$ vines and 10 leaf samples without symptoms $\times 10$ vines) were randomly selected from each field and control field. Samples were transported to the laboratory in plastic bags on ice in an ice chest. Isolations were attempted within $24 \mathrm{~h}$ of collection. Leaf samples were bulked and assayed for $X$. fastidiosa using assays described previously. Two-centimeterlong petiole segments were surface-sterilized in $70 \%$ ethanol for 1 min followed by $3 \mathrm{~min}$ in $1 \%$ sodium hypochlorite and washed in four successive changes of sterile distilled water. Segments were ground in $1 \mathrm{ml}$ of phosphate-buffered saline with a mortar and pestle and plated onto periwinkle wilt and Pierce's disease (PD3) media (8-10). Plates were sealed with Parafilm and incubated at $28^{\circ} \mathrm{C}$ in the dark and observed for microbial growth daily. Presumptive $X$. fastidiosa colonies usually appeared 7 to 15 days after plating. Pathogen identity was confirmed by ELISA (38) and IC-PCR (24,27). X. fastidiosa strain Temecula (ATCC700964), collected from grape in Temecula, CA, was used as a reference control in this study. $X$. fastidiosa cells were grown on a modified periwinkle wilt (PW) with Gelrite (18).

Vector monitoring. Monitoring of the GWSS vector started in March 2001. In each field, four yellow sticky cards (17.5 by $22.5 \mathrm{~cm})(2,3)$ were clipped onto 1.5-m-long stakes and GWSS catches were counted every week. Sampling started 1 March 2001 (Julian date 60). In addition, GWSS catches on yellow sticky cards positioned in citrus, almond, stone fruits, and berries were counted every week. Six 12-m-high poles were used, adjacent to eucalyptus bordering citrus $15 \mathrm{~m}$ from grapes. Each pole had a pulley on top with a rope attached that allowed yellow sticky

TABLE 1. Characteristics of 12 vineyards surveyed for Pierce's disease

\begin{tabular}{|c|c|c|c|c|c|c|}
\hline Field & Cultivar & Proximity $^{\mathrm{a}}$ & Age & Vine spacing & No. of vines & $\begin{array}{l}\text { Avgerage no. } \\
\text { of GWSS per trap }\end{array}$ \\
\hline 1 & Flame Seedless & Citrus & 6 & $3.90 \times 2.04 \mathrm{~m}$ & 1,000 & $0.00 \pm 0.00$ \\
\hline 2 & Redglobe & Berries/citrus & 8 & $3.60 \times 1.50 \mathrm{~m}$ & 1,000 & $3.07 \pm 1.21$ \\
\hline 3 & Autumn Royal & Grape & 6 & $3.60 \times 1.80 \mathrm{~m}$ & 840 & $3.07 \pm 1.21$ \\
\hline 4 & Redglobe & Citrus & 9 & $3.75 \times 2.28 \mathrm{~m}$ & 1,000 & $3.07 \pm 1.21$ \\
\hline 5 & Crimson Seedless & Citrus & 6 & $3.60 \times 1.80 \mathrm{~m}$ & 1,000 & $4.66 \pm 1.94$ \\
\hline 6 & Flame Seedless & Grape & 8 & $3.90 \times 2.04 \mathrm{~m}$ & 1,000 & $7.35 \pm 2.19$ \\
\hline 7 & Flame Seedless & Citrus & 10 & $3.66 \times 2.13 \mathrm{~m}$ & 1,000 & $3.23 \pm 1.57$ \\
\hline 8 & Flame Seedless & Grape & 8 & $3.60 \times 1.74 \mathrm{~m}$ & 1,000 & $3.07 \pm 1.21$ \\
\hline 9 & Redglobe & Citrus & 6 & $3.54 \times 1.35 \mathrm{~m}$ & 1,000 & $2.00 \pm 0.98$ \\
\hline 10 & Crimson Seedless & Grape & 8 & $3.60 \times 1.80 \mathrm{~m}$ & 1,000 & $3.07 \pm 1.21$ \\
\hline 11 & Redglobe & Citrus/grape & 12 & $3.60 \times 1.80 \mathrm{~m}$ & 1,450 & $35.66 \pm 10.01$ \\
\hline 12 & Redglobe $^{c}$ & Citrus & 6 & $3.90 \times 2.04 \mathrm{~m}$ & 1,000 & $0.00 \pm 0.00$ \\
\hline
\end{tabular}

a Surrounding crops.

${ }^{\mathrm{b}}$ Average number of glassy-winged sharpshooter (GWSS) per trap in March 2001 across all crops (10.76 \pm 2.82 ). Data taken prior to the onset of this study.

c Control field used to detect background contamination. 
cards to be suspended at $2,4,6,8,10$, and $12 \mathrm{~m}$ above the ground. The six pulley systems were installed in three grapecitrus interfaces using eucalyptus as support. Pulley traps were also monitored every week.

Runs analysis. Ordinary runs analysis, which utilizes binary data, was used to assess the presence or absence of aggregation of diseased individuals within and across rows in a population of diseased plants (22). The analysis was conducted within and across rows using disease incidence data separately for each row or column and calculated by quadrat on each assessment date (22). Ordinary runs analysis was also conducted within each row on disease incidence data collected on individual vines on each disease assessment date. The percentage of rows with clustered patterns of disease was calculated and the location of rows with clustered patterns of PD was noted. If diseased vines in a row resulted from bacteria spreading from vine-to-vine, then aggregation (clustering) of diseased vines would be expected. Thus, there would be few runs, and the $Z$ statistic would be a large negative number. However, if the bacteria are not spreading from vine-tovine, a random mixing of healthy and infected vines is expected, and a corresponding large number of runs. The null hypothesis evaluated in this test is that the sequence of infected vines is random. If $Z$ statistic is less than -1.64 , there is a clustering of diseased vines. Statistical methods were then used to interpret the spatial patterns of PD vines including ordinary runs analysis (22) and geostatistics $(21,25,44)$.

Spread of PD. Incidence of PD was regressed on distance without transformation and after $\operatorname{logit}(y)-\log (x), \operatorname{logit}(y)-\operatorname{linear}(x)$, $\log (x)-\log (y)$, and $\log (x)$ - linear $(x)$. The coefficient of determination, the standard error and significance of the estimated slope parameters, the mean square errors, and the patterns of residuals versus predicted values were used to evaluate the goodness-of-fit of data and to choose the best regression models (42).

Geostatistical analysis of disease within vineyard. Geostatistical analysis was used to further characterize changes in spatial patterns of disease or pathogen populations in time and space. Geostatistical results are presented as semivariograms, which represent the average of squared differences in values between pairs of samples separated by a given distance $(6,7,23,39)$. Semivariograms are calculated for all directions combined or for specific directions $\left(0^{\circ}, 45^{\circ}, 90^{\circ}\right.$, and $135^{\circ}$ azimuth $)$ to test for anisotropy, a characteristic of regionalized variables that do not have the same proprieties in all directions. Zero represents the direction in which the vineyard rows were oriented. In this study, semivariograms were constructed on the untransformed disease incidence data from the 10-vine quadrats using Gamma Design Software (version 5.3) for GeoStatistics for the Environmental Sciences (Plainwell, MI). Semivariograms were prepared for each field by plotting semivariance versus distance $(h)$ for all directions. Semivariance values that start out small and increase with distance indicate spatially dependent samples (39). The distance at which the semivariance approaches a constant value is called the range of spatial dependence and indicates the distance beyond which the sample values are no longer correlated with each other (39). Samples separated by distances closer than the range are spatially correlated, whereas those separated by distances greater than the range are not spatially correlated. The constant value at which the semivariograms level off is the sill or sample variance. The sill represents spatially independent variance. The nugget variance is the $Y$ intercept of the variogram model. Nugget variance represents variation not spatially dependent over the range examined. Linear and nonlinear models were fitted to semivariograms by least squares regression using Statistical Analysis Systems version 8.0 (SAS Institute, Cary, NC). The incidence data were regressed on distance without transformation and after the Gaussian, spherical, linear, linear to sill, and exponential models, were used to describe semivariograms $(6,7,11,39)$. The coefficient of determination, structural variance (proportion of spatial structure), and mean square error were used to evaluate the goodness-of-fit of data and to choose the best regression model $(6,7,39)$. Anisotropy was determined by comparison of semivariogram characteristics. Oriented semivariograms that displayed differences among semivariogram characteristics for different directional orientations indicated anisotropy or directionality in the degree of spatial dependence $(6,7,11,39)$. The semivariograms for which geostatistical analysis was appropriate are presented.

TABLE 2. Incidence and ordinary runs analysis of the aggregation of Pierce's disease in 11 California vineyards

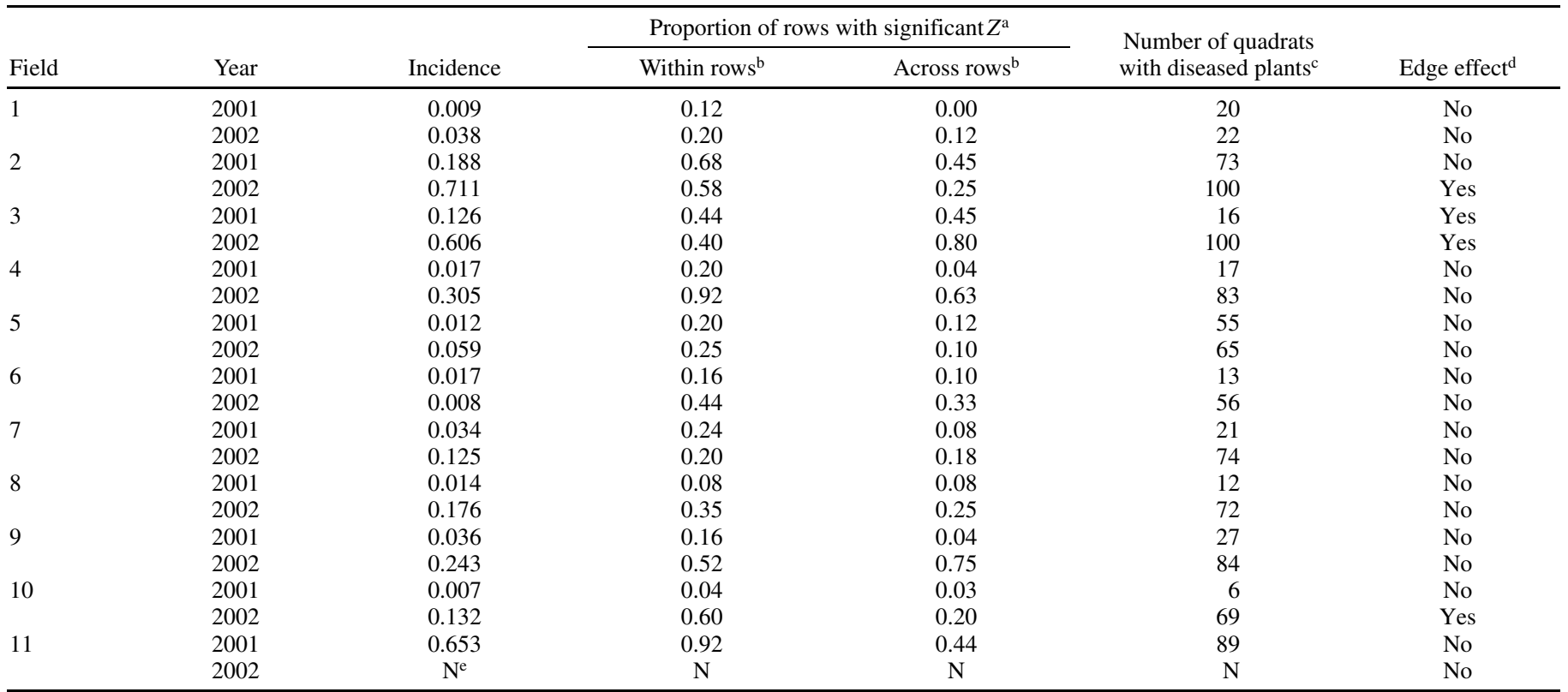

a Ordinary runs analysis was performed separately along each row or each transect across rows for each combination of field and year. Values are proportions of tests that indicated significant aggregation of diseased vines at $P=0.05$. No disease was observed in control field (field 12).

${ }^{\mathrm{b}}$ Within-row number $=40$; across-row number $=21$ to 25 .

c Total number of quadrats $=100 ; 10$ plants per quadrat.

d Aggregation of disease vines at the origin.

e No assessment data available for that year or too few data points were available to allow calculation. 


\section{RESULTS}

Isolation, culture, and detection of $\boldsymbol{X}$. fastidiosa. PD bacteria were confirmed in laboratory-based assays in symptomatic grapevines. Eighty-five percent of the symptomatic vines gave positive ELISA reactions. The bacteria, identified as $X$. fastidiosa, were isolated from the symptomatic vines. $X$. fastidiosa did not differ morphologically (light microscopy), serologically (ELISA), or in its growth characteristics on PW or PD3 medium compared with the reference $X$. fastidiosa strain used as a control. Selected strains of the isolated bacteria produced a band of $600 \mathrm{bp}$ after PCR amplification with the specific primers RST31 and RST33. Isolation, ELISA, and PCR provided detection and confirmation of identity of $X$. fastidiosa with PD symptoms observed in the vineyard. Disease symptom types observed in all vineyards included drying or scorching of leaves, extensive marginal scalding of leaves, premature senescence of numerous leaves, irregular zones of bark maturity, necrosis, and chlorosis of leaf margins $(2,28)$. Disease incidence ranged from $<1 \%$ in field 1 (Flame Seedless) in 2001 to $71 \%$ in field 2 (Redglobe) in 2002 (Table 2). Disease incidence was greater in 9 of 11 vineyards during the 2002 production season compared with that of the 2001 season. Symptoms of PD were not detected in the control field that was used to detect background contamination.

Vector monitoring. The efforts to capture or trap potential PD vectors in the lower San Joaquin Valley during the 2001 to 2003 production years have proved that the GWSS is the only vector.

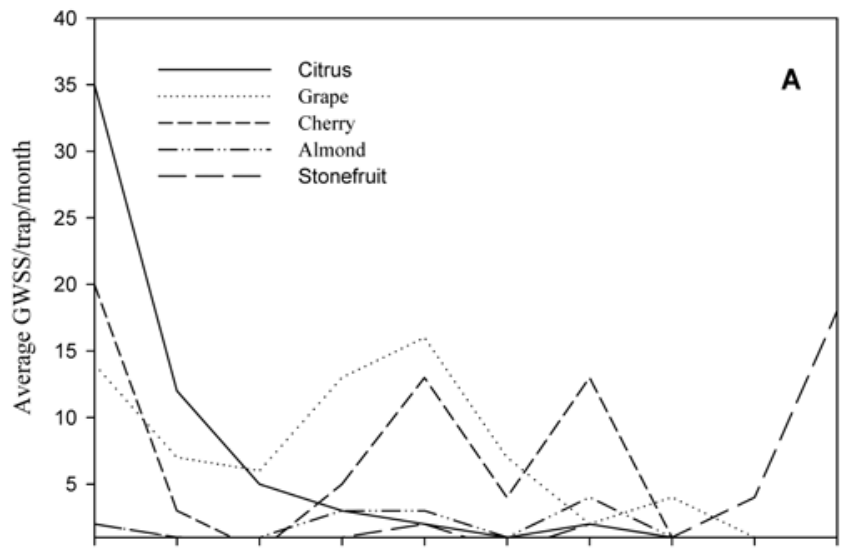

Mar 01 Apr 01 May 01 Jun 01 July 01 Aug 01 Sep 01 Oct 01 Nov 01 Dec 01

Date

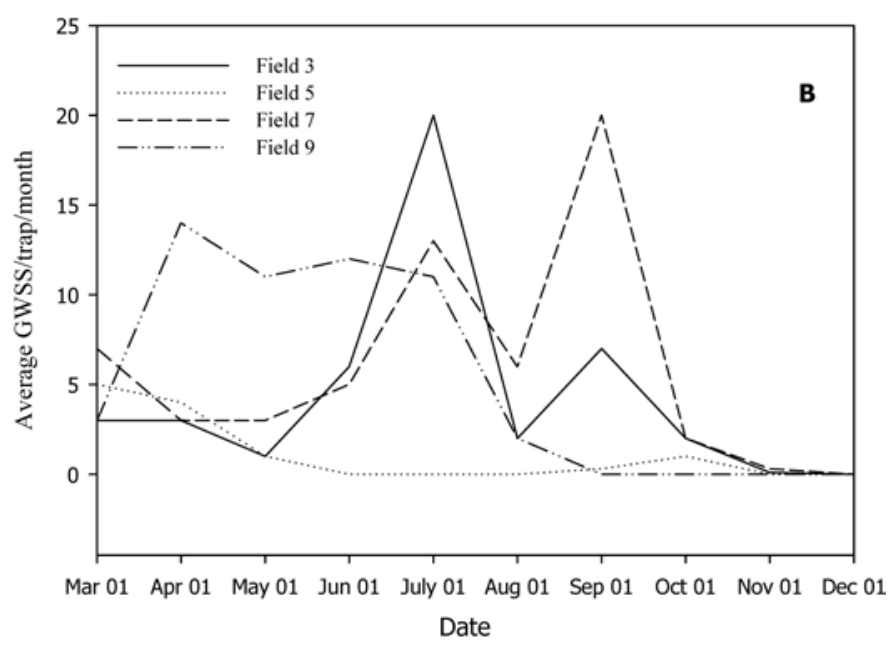

Fig. 1. Monthly means of Homalodisca coagulata (glassy-winged sharpshooter [GWSS]) obtained A, within crops and $\mathbf{B}$, selected fields with sticky traps in the area-wide management project study during 10 consecutive months of sampling in 2001.
No other sharpshooters were observed in weekly trapping and sweep net capture efforts. Data for 2002 are not presented because of low GWSS population and extensive chemical treatment recommendation by the U.S. Department of Agriculture-APHISPlant Protection and Quarantine (PPQ) to eradicate the pests. Means of GWSS per trap in different crops and selected fields are shown in Figure 1. GWSS populations varied among the crops (Fig. 1A). The peak GWSS capture per trap in March 2001 was $35.06 \pm 6.18$ for citrus, $14.06 \pm 2.27$ for grape, $19.33 \pm 2.02$ for cherry, $9.13 \pm 0.83$ for almond, and $2.38 \pm 0.03$ for stone fruits in March 2001 (Fig. 1A). The average number of GWSS per trap per month also varied among the selected fields (Fig. 1B). Mean yellow sticky trap capture of GWSS at the beginning of this study ranged from 0 in field 1 to 35.06 per trap in field 11 (Table 1; Fig. $1 B$ ) in 2001. GWSS catches on the pulley traps (vertical distribution) per trap from March 2001 to March 2002 varied from year to year. Mean GWSS capture in 2002 was lower than in 2001. Means GWSS captures were $20.92 \pm 2.02,11.47 \pm 2.13$, $24.72 \pm 5.22,17.21 \pm 3.82,21.01 \pm 4.19$, and $27.69 \pm 5.61$ at trap heights of $2,4,6,8,10$, and $12 \mathrm{~m}$, respectively, in 2001. In 2002, they were $5.13 \pm 2.68,1.87 \pm 0.30,5.21 \pm 2.56,3.22 \pm 1.26$, $4.45 \pm 1.31$, and $10.01 \pm 2.79$ at trap heights of $2,4,6,8,10$, and $12 \mathrm{~m}$, respectively.

Runs analysis. Because of lack of a trend in the proportion of rows and transects containing clusters, only final disease incidence data on day 241 in 2001 and on day 246 in 2002 are presented. Total numbers of diseased vines along transects display-
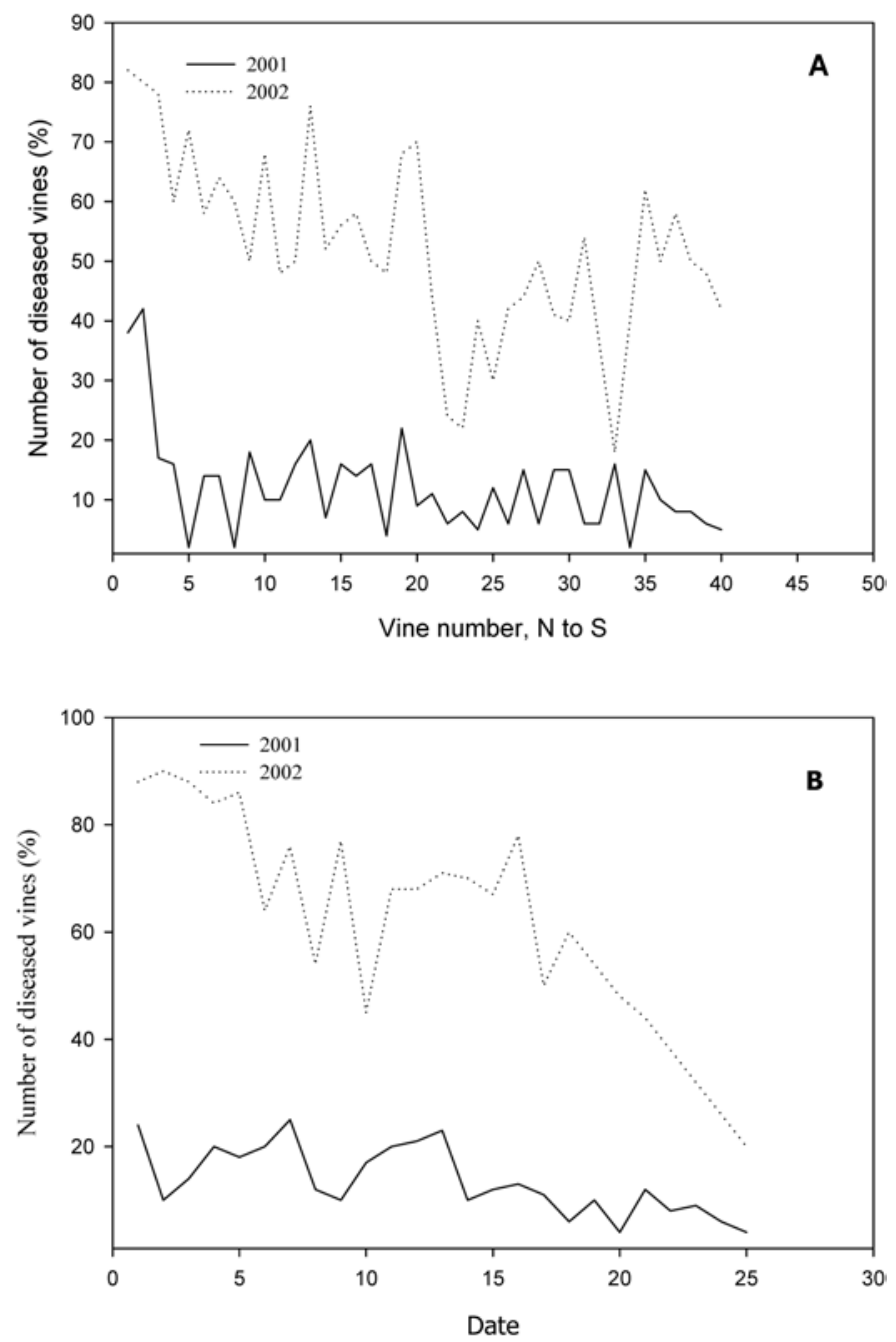

Fig. 2. A, Total diseased vines along transects displaying a disease gradient or edge effect in field 3 in 2001 and 2002. B, Total diseased vines for rows displaying a disease gradient or edge effect in field 3 in 2001 and 2002. 
ing a disease gradient or edge effect in selected fields is also presented (Fig. 2). In these two fields, the disease incidence decreased with increasing distance from inoculum source. The frequency of significant within-row aggregation in disease varied among fields, from $4 \%$ of rows in field 10 to $58 \%$ of rows in field 2 during 2001 (Table 2). In 2002, both within-row and across-row aggregation increased compared with that in 2001. The frequency of significant within-row aggregation ranged from 20 to $92 \%$ (Table 2) of rows within individual fields, and the frequency of across-row aggregation ranged from 12 to $80 \%$ among fields (Table 2). For most fields, the frequency of significant aggregation within rows was greater than the frequency across rows.

Spread of PD. In 2001, a disease gradient was present only in field 2, whereas in 2002, disease gradients were observed in fields 2,3 , and 10 . Disease gradients were best described by the $\operatorname{logit}(x)-$ linear $(y)$ model. Incidence of PD decreased with increasing distance from inoculum source (Fig. 3). A pronounced "edge effect" was observed in field 2 and field 3 not adjacent to citrus where diseased vines were concentrated along one side of the vineyard block. In the overall analysis, high PD incidence was not consistently detected in rows bordering the citrus. The final percentage of quadrats with PD symptoms ranged from 6\% in field 10 (cv. Crimson Seedless) in 2001 to $100 \%$ in field 2 (cv. Redglobe) and field 3 (cv. Autumn Royal) in 2002 (Table 2).

Geostatistical analysis of disease within field. The semivariogram shapes were described by a variety of models within and
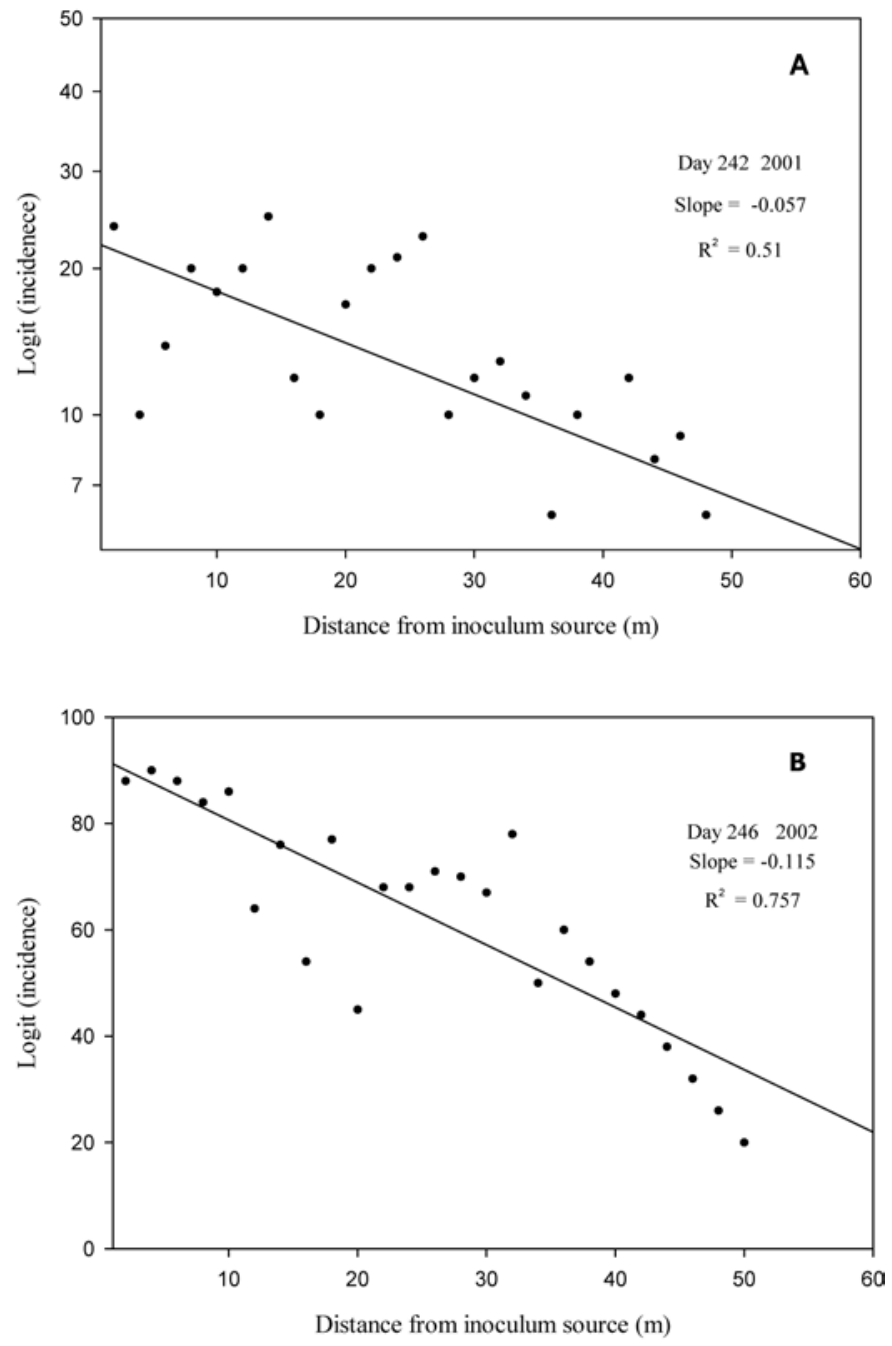

Fig. 3. Spread of Pierce's disease incidence in field 3 in the area-wide management project study during 2001 and 2002 production. Pierce's disease spread was quantified using the $\operatorname{logit}(x)-\operatorname{linear}(x)$ model $\mathbf{A}$, on day 241 in 2001 and $\mathbf{B}$, on day 246 in 2002. among fields, including spherical, exponential, and linear forms (Table 3). In most fields, nugget variance ( $Y$ intercept) remained small in 2002 compared with 2001 . This indicated a strong spatial structure with a large proportion of the variation explained by spatial distribution (Table 3). In field 2 in 2001, semivariograms for the within-row $\left(0^{\circ}\right)$, across-row $\left(90^{\circ}\right)$, and diagonal $\left(45^{\circ}\right.$, $135^{\circ}$ ) directions fit a linear model and the same trend was observed in 2002 (Table 3). In field 3 in 2001, semivariograms for within-row analyses were described by an exponential model, whereas the diagonal $\left(45^{\circ}, 135^{\circ}\right)$ direction fit the linear model and semivariograms for $90^{\circ}$ were closest to a spherical model. In the same field in 2002, semivariograms for the within-row analyses were described by a linear model, whereas the across-row $\left(90^{\circ}\right)$ and diagonal $\left(45^{\circ}, 135^{\circ}\right)$ directions fit an exponential model (Table 3). In fields 7 and 10 in 2002, the semivariograms for within-row, across-row $\left(90^{\circ}\right)$, and diagonal $\left(45^{\circ}, 135^{\circ}\right)$ directions fit a linear model (Table 3). Characteristic changes in semivariograms are illustrated in Figures 4 and 5. Combined semivariograms indicated a strong degree of spatial dependence for fields 2 and 3 (Fig. 4). However, semivariograms did not indicate a strong degree of spatial dependence for fields 7 and 10. The shape of oriented semivariograms and the magnitude of semivariance changed with field location and grapevine cultivar. The semivariograms for all directions were flat during early epidemics in 2001 (Fig. 5), indicating that disease in individuals' quadrats was not spatially related with disease in neighboring quadrats and variation between quadrat was random. In 2002, disease became more spatially dependent and the degree of spatial dependence differed with the direction of orientation (strong anisotropy) (Fig. $5)$. A disease gradient was apparent in the within-row $\left(0^{\circ}\right)$, acrossrow $\left(90^{\circ}\right)$ and diagonal $\left(45^{\circ}, 135^{\circ}\right)$ directions in fields 2 and 7 , whereas the semivariograms for all directions in fields 3 and 10 were nearly flat, indicating little disease gradient in within-row, across-row, and diagonal directions.

TABLE 3. Semivariogram characteristics and selected model parameters of final Pierce's disease incidence for epidemics caused by Xylella fastidiosa in commercial vineyards in 2001 and 2002

\begin{tabular}{|c|c|c|c|c|}
\hline Year/field & Direction $^{\mathrm{a}}$ & Model $^{\mathrm{b}}$ & $\begin{array}{l}\text { Nugget }^{\mathrm{c}} \\
\left(\mathrm{c}_{0} \text { or } \mathrm{a}\right)\end{array}$ & Sill $^{\mathrm{d}}$ \\
\hline \multirow[t]{4}{*}{ 2001/field 2} & 0 & Linear & 0.266 & 0.655 \\
\hline & 90 & Linear & 0.277 & 0.661 \\
\hline & 45 & Linear & 0.253 & 0.642 \\
\hline & 135 & Linear & 0.280 & 0.669 \\
\hline \multirow[t]{4}{*}{ 2001/field 3} & 0 & Exponential & 0.210 & 0.785 \\
\hline & 90 & Spherical & 0.194 & 0.644 \\
\hline & 45 & Linear & 0.266 & 0.601 \\
\hline & 135 & Linear & 0.207 & 0.659 \\
\hline \multirow[t]{4}{*}{ 2002/field 2} & 0 & Linear & 0.086 & 0.291 \\
\hline & 90 & Linear & 0.091 & 0.256 \\
\hline & 45 & Linear & 0.099 & 0.253 \\
\hline & 135 & Linear & 0.083 & 0.236 \\
\hline \multirow[t]{4}{*}{ 2002/field 3} & 0 & Linear & 0.098 & 0.981 \\
\hline & 90 & Exponential & 0.063 & 0.936 \\
\hline & 45 & Exponential & 0.131 & 0.996 \\
\hline & 135 & Exponential & 0.101 & 0.770 \\
\hline \multirow[t]{4}{*}{ 2002/field 7} & 0 & Linear & 0.200 & 0.523 \\
\hline & 90 & Linear & 0.175 & 0.486 \\
\hline & 45 & Linear & 0.205 & 0.516 \\
\hline & 135 & Linear & 0.201 & 0.516 \\
\hline \multirow[t]{4}{*}{ 2002/field 10} & 0 & Linear & 0.268 & 0.671 \\
\hline & 90 & Linear & 0.263 & 0.606 \\
\hline & 45 & Linear & 0.244 & 0.584 \\
\hline & 135 & Linear & 0.256 & 0.559 \\
\hline \multicolumn{5}{|c|}{$\begin{array}{l}\text { a Direction of analysis refers to orientation of lag neighbors used in anlysis in } \\
\text { degrees azimuth }\left(0^{\circ}=\text { within rows }\right) \text {. }\end{array}$} \\
\hline
\end{tabular}




\section{DISCUSSION}

Results from this study suggest that GWSS is the most likely vector observed in the area-wide management pilot project study. No other sharpshooters were observed in weekly trapping. Each field in this study had been infested by GWSS prior to the onset of the study. For the same reason, no relationship between PD incidence and GWSS was attempted. Incidence of PD more than doubled in most of these vineyards in 2002 compared with that in 2001. The establishment and spread of GWSS may be a major factor in $X$. fastidiosa transmission and increased incidence of PD.

The incidence of PD varied among fields. The average frequency of PD symptoms for vines assessed in the 11 vineyards varied greatly from $<1$ to $65 \%$ in 2001 . Results from this study confirm previous observations that high GWSS densities were related to increased PD incidence $(3,13,18-20,26,33,37,41)$. In California, differences in tolerances to $X$. fastidiosa have been reported among $V$. vinifera cultivars $(28,35)$. Differences among grape cultivars are reportedly due to their overwinter recovery rates from severe infections, vector preference, or susceptibility to severe infection $(29,30)$. Variation in epidemics was noted among
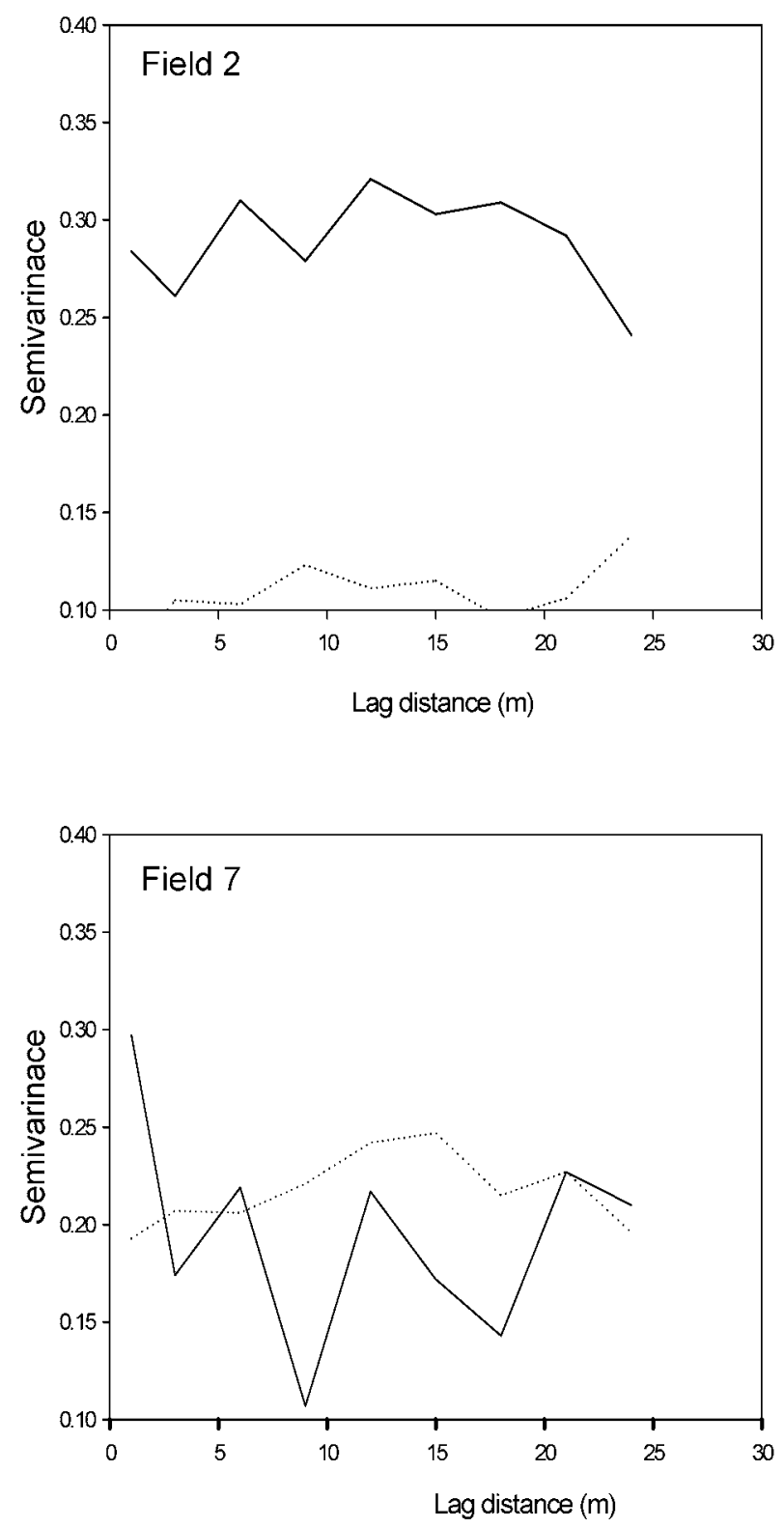

fields and that this is probably the result of several interrelated factors, including host resistance to $X$. fastidiosa, environment, and the numbers and proximity of inoculum sources outside the experimental sites.

Edge effects were not common and this probably reflects the biology of the GWSS. We observed an edge effect in both field 3 (cv. Autumn Royal) and field 10 (cv. Crimson Seedless) not adjacent to citrus (Tables 1 and 2). Purcell (28) found a consistent edge effect with $X$. fastidiosa vectored by the BGSS with disease most concentrated near riparian vegetation. This finding should not be expected to hold true for the GWSS because it has longer mouthparts that allow it to feed on older stems of grape plants. GWSS is considered to be a highly polyphagous insect species utilizing numerous plant species as both feeding and oviposition hosts $(14,36,37)$. Spread of disease at about $50 \mathrm{~m}$ from the source was observed, which suggests that GWSS as well as other sharpshooters (28) can transmit $X$. fastidiosa at further distances from inoculum source.

Data from vertical distribution (pulley traps) show that GWSS may fly up to $12 \mathrm{~m}$ high. This shows that the vectors may reach other vineyards located several kilometers away from inoculum
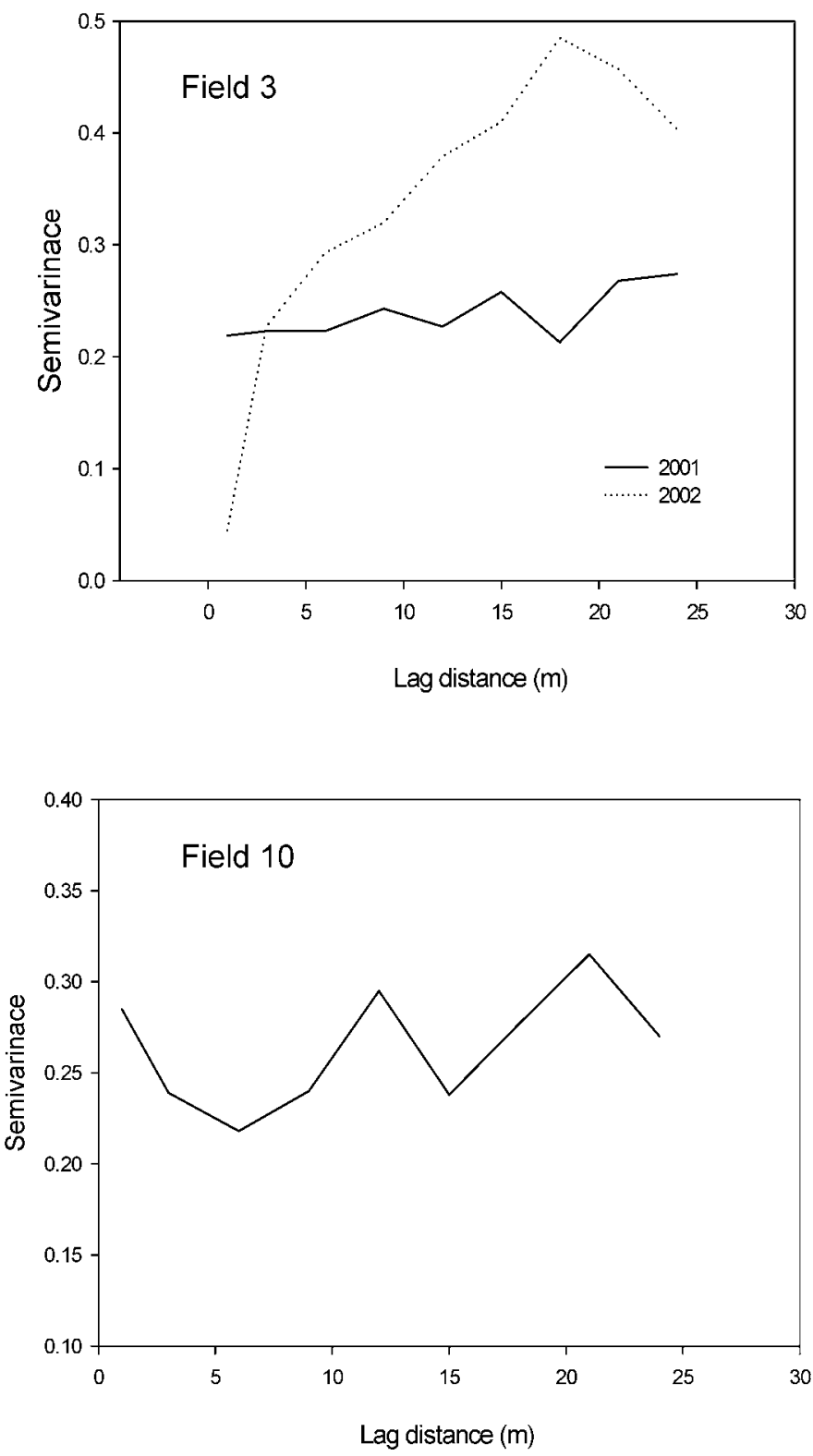

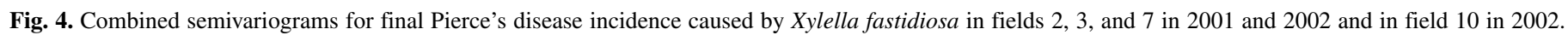
The orientation of the field rows corresponds to angle of zero. 
sources depending on weather conditions. Seasonal trap data showed higher mean GWSS capture per trap on citrus (35.0) than on cherry (19.0), grape (14.0), almond (9.0), and other stone fruit (2.0), with peak capture in March 2001. This finding confirms earlier reports that citrus is the preferred overwintering host for GWSS $(3,26)$.

This finding was unexpected because in the Temecula Valley (South California), a mixed region of grape-citrus where vineyards are adjacent to citrus, the disease intensity decreased with increased distance from the citrus (26). The lack of evidence for disease gradient in most of the vineyards implies that (i) either the invading population of GWSS is not infective and (ii) the later
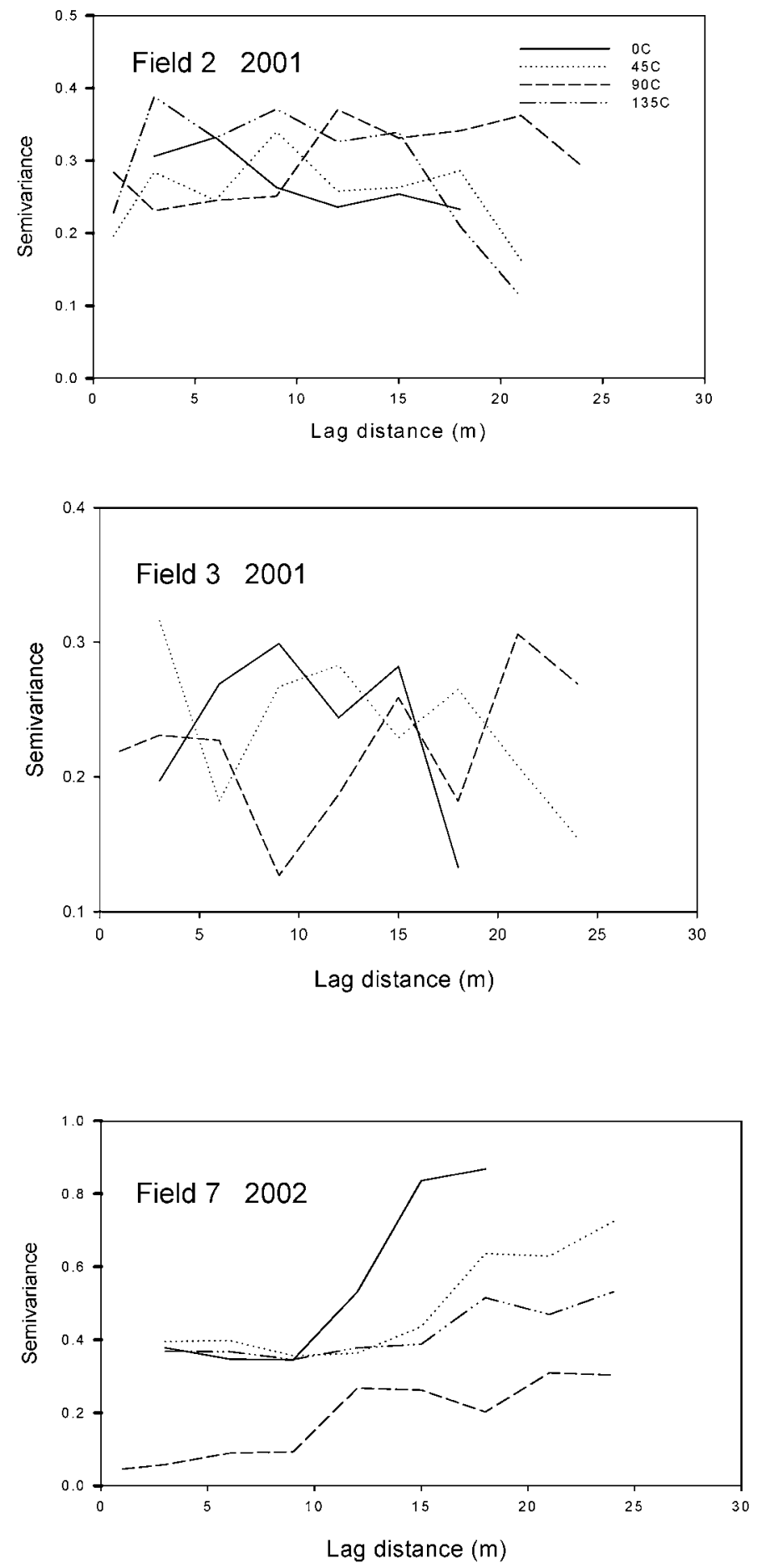

movements within vineyards after arriving are most important in spreading infections that resulted in symptoms recorded.

Analysis of the data with ordinary runs analysis indicated that within-row aggregation of disease was dominant in all fields in 2001 and 2002. The frequency of across-row aggregation was greater than the frequency of within-row aggregation in fields 3 and 9 . This increase was probably due to simultaneous spread of $X$. fastidiosa within adjacent rows of plants. Our results are consistent with the secondary spread of $X$. fastidiosa as an important factor of PD spread by GWSS. Secondary transmission within vineyards has been observed in Florida (1) where vine-to-vine spread is significant early in the season, resulting in severe infec-
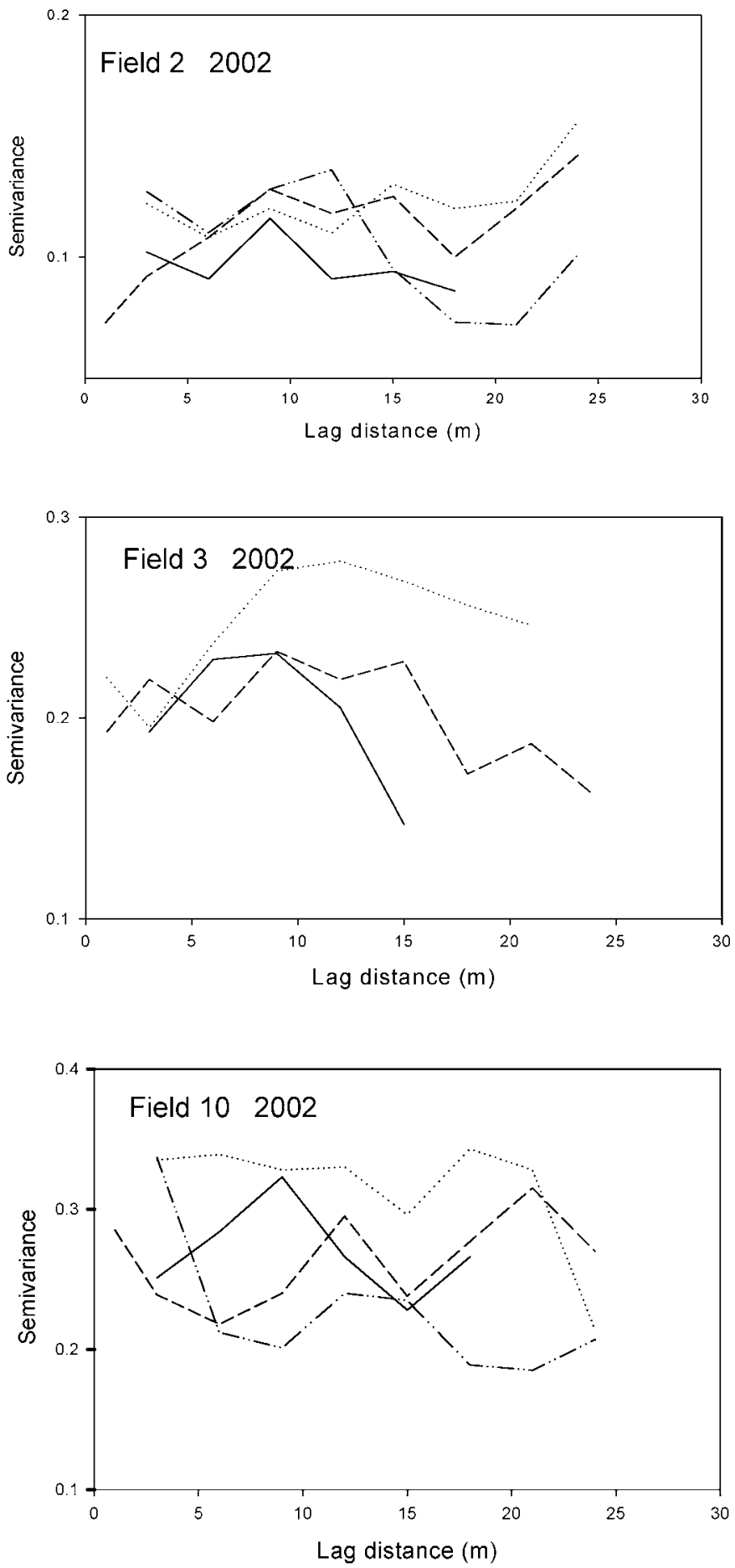

Fig. 5. Oriented semivariograms for final Pierce's disease incidence caused by Xylella fastidiosa in fields 2 and 3 in 2001 and in fields 2,3 , 7, and 10 in 2002 . The orientation of the field rows corresponds to angle of zero. 
tions, and later in the season, $X$. fastidiosa spreads through infective leafhoppers from alternate hosts and infected vines. In California, however, vine-to-vine spread of $X$. fastidiosa vectored by BGSS was limited in how it affected the spread of chronic PD because most summer infections do not persist through the summer and fall seasons (19).

Within-row disease should be more aggregated where vine-tovine spread is important because vines are much closer than across rows. The only demonstrated method for obtaining naturally infected vines with PD under vineyard conditions is through vector (e.g., GWSS) transmission of $X$. fastidiosa $(13,30)$. Therefore, the distribution of PD in the field is a reflection of the feeding pattern of infectious vectors carrying the bacteria and other unknown factors. The aggregation of PD could occur as a result of $X$. fastidiosa-inoculative vectors that move plant-to-plant rather quickly in the row. That is, one infectious vector could inoculate two or more adjacent healthy vines with the bacterium from a given source plant that may or may not have been close to the plants that were inoculated.

$X$. fastidiosa spread in California has been reported from inoculum sources in plants outside the vineyards $(12,16,28)$, suggesting that vector acquisition of $X$. fastidiosa from various plant species can be an important factor in the spread of crop diseases caused by $X$. fastidiosa. The presence of several potential X. fastidiosa host weed species in fields in California makes it possible for vector populations to acquire the bacteria and infect healthy vines, and subsequently move within the vineyard $(3,12,14)$. Establishment of severe $X$. fastidiosa infections by GWSS inoculations near basal portions of canes or spurs during summer months or fall and during winter could have increased the chance of vine-tovine spread of bacteria (14).

PD incidence in most of the fields examined showed strong spatial dependence and anisotropy when disease more than doubled in 2002. Semivariograms were best described using a variety of linear and nonlinear models in this study. The linear and exponential models provided the best fits. However, the biological significance of fitting specific model types to semivariograms also is unclear. For fields 2 and 3 in 2002, the semivariance did not reach a plateau but increased linearly, typical of cases with a disease gradient or edge effect $(4,25,39)$. This effect was not evident in 2001 (Fig. 4, field 2). For all vineyards, the shape of semivariograms changed with year. Overall, spatial dependence was indicated by semivariograms in 2002 but not in 2001 .

This study suggests that the GWSS was likely the vector of PD bacterium. Overall, surrounding environment (grape-citrus) did not affect disease gradient. The pathogen spread occurred within a field resulting in a clustered pattern, an indication of possible vine-to-vine transmission. Based on these results, effective PD management is likely to be based on practices that reduce insect population densities entering and remaining in the vineyards' diseased vines and on the use of resistant cultivars. Also, removal of $X$. fastidiosa-infected vines and early detection of surrounding vines for new infections and refinement of detection methods to limit within-field inoculum should be practiced. We are in the process of further analyzing the spatial patterns of $X$. fastidiosa vectored by BGSS under natural field conditions to elucidate and quantify the importance of dispersal mechanisms operating in this pathosystem and devise cultural management strategies that will be effective in limiting pathogen dispersal.

\section{ACKNOWLEDGMENTS}

This project was supported in part by the USDA APHIS. We thank A. H. Purcell (UC Berkeley), S. Wegulo (UC Riverside), R. Groves, and M. Olanya (USDA-ARS) for critical review of the manuscript; D. Wade for technical assistance; and D. Elms and R. Yacoub from California Department of Food and Agriculture for assistance in collecting and managing GWSS data.

\section{LITERATURE CITED}

1. Adlerz, W. C., and Hopkins, D. L. 1979. Natural infectivity of two sharpshooter vectors of Pierce's disease of grape in Florida. J. Econ. Entomol. 72:916-919.

2. Anonymous. 1992. Grape Pest Management. 2nd ed. Univ. Calif. Div. Nt. Res. Publ. 3343.

3. Blua, M. J., Phillips, P. A., and Redak, R. A. 1999. A new sharpshooter threatens both crops and ornamentals. Calif. Agric. 53:22-25.

4. Chellemi, D. O., Rohrbach, K. G., Yost, R. S., and Sonoda, R. M. 1988. Analysis of spatial pattern of plant pathogens and diseased plants using geostatistics. Phytopathology 78:221-226.

5. Costa, H. S., Blua, M. S., Bethke, A., and Redak, R. A. 2000. Transmission of Xylella fastidiosa to oleander by the glassy-winged sharpshooter, Homalodisca coagulata. HortScience 35:1265-1267.

6. Cressie, N. 1985. Fitting variogram models by weighted least squares. Math. Geol. 17:563-586.

7. Cressie, N. 1988. Spatial prediction and ordinary kriging. Math. Geol. 20:405-421.

8. Davis, M. J., Purcell, N. W., and Thomson, S. V. 1978. Pierce's disease of grapevines: Isolation of the causal organism. Science 199:75-77.

9. Davis, M. J., Purcell, N. W., and Thomson, S. V. 1980. Isolation medium for the Pierce's disease bacterium. Phytopathology 70:425-429.

10. Davis, M. J., Raju, B. C., Brlansky, R. H., Lee, R. F., and Timmer, L. W. 1983. Periwinkle wilt bacterium: Axenic culture, pathogenicity, and relationships to other gram negative, xylem-inhabiting bacteria. Phytopathology 73:1510-1515.

11. Di, H. J., Trangmar, B. B., and Kemp, R. A. 1989. Use of geostatistics in designing sampling strategies for soil survey. Soil Sci. Soc. Am. J. 53:1163-1167.

12. Feil, H., Feil, W. S., and Purcell, A. H. 2003. Effects of date of inoculation on the within-plant movement of Xylella fastidiosa and persistence of Pierce's disease within field grapevines. Phytopathology 93:244-251.

13. Feil, H., and Purcell, A. H. 2001. Temperature-dependent growth and survival of Xylella fastidiosa in vitro and in potted grapevines. Plant Dis. 85:1230-1234

14. Freitag, J. H., and Frazier, N. W. 1954. Natural infectivity of leafhopper vectors of Pierce's disease virus of grape in California. Phytopathology 44:7-11.

15. Gregory, P. H. 1968. Interpreting plant disease dispersal gradients. Annu. Rev. Phytopathol. 6:189-212.

16. Hewitt, W. B., Frazier, N. W., Jacob, H. E., and Freitag, J. H. 1942. Pierce's disease of grapevines. Calif. Agric. Exp. Stn. Circ. 353:1-32.

17. Hewitt, W. B., Houston, B. R., Frazier, N. W., and Freitag, J. H. 1946. Leafhopper transmission of the virus causing Pierce's disease of grape and dwarf of alfalfa. Phytopathology 36:117-128.

18. Hill, B. L., and Purcell, A. H. 1995. Multiplication and movement of Xylella fastidiosa within grape and four other plants. Phytopathology 85:1368-1372.

19. Hill, B. L., and Purcell, A. H. 1997. Populations of Xylella fastidiosa in plants required for transmission by an efficient vector. Phytopathology 87:1197-1201.

20. Hopkin, D. L., and Purcell, A. H. 2002. Xylella fastidiosa: Cause of Pierce's disease of grapevine and other emergent diseases. Plant Dis. 86:1056-1066

21. Larkin, R. P., Gumpertz, M. L., and Ristaino, J. B. 1995. Geostatistical analysis of Phytophthora epidemic development in commercial bell pepper fields. Phytopathology 85:191-203.

22. Madden, L. V., Louie, R., Abt, J. J., and Knoke, J. K. 1982. Evaluation of tests for randomness of infected plants. Phytopathology 72:195-198.

23. Matherson, G. 1963. Principals of geostatistics. Econ. Geol. 58:1246-1266.

24. Minsavage, G. V., Thompson, C. M., Hopkins, D. L., Leite, B. C., and Stall, R. E. 1994. Development of a polymerase chain reaction protocol for detection of Xylella fastidiosa in plant tissue. Phytopathology 84:456461.

25. Munkvold, G. P., Duthie, J. A., and Marois, J. J. 1993. Spatial patterns of grapevines with Eutypa dieback in vineyards with or without perithecia. Phytopathology 83:1440-1448.

26. Perring, T. M., Farrar, C. A., and Blua, M. J. 2001. Proximity to citrus influences Pierce's disease in Temecula Valley vineyards. Calif. Agric. 55:13-18.

27. Pooler, M. R., Myung, I. S., Bentz, J., Sherald, J., and Hartung, J. S. 1997. Detection of Xylella fastidiosa in potential insects by immunomagnetic separation and nested polymerase chain reaction. Lett. Appl. Microbiol. 25:123-126.

28. Purcell, A. H. 1974. Spatial patterns of Pierce's disease in the Napa Valley. Am. J. Enol. Vitic. 25:162-167.

29. Purcell, A. H. 1980. Environmental therapy for Pierce's disease of grapevines. Plant Dis. 64:388-390.

30. Purcell, A. H. 1981. Vector preference and inoculation efficiency as com- 
ponents of varietal resistance to Pierce's disease in European grapes. Phytopathology 71:429-435.

31. Purcell, A. H., and Finley, A. H. 1979. Evidence for noncirculative transmission of Pierce's disease bacterium by sharpshooter vectors. Science 206:839-841.

32. Purcell, A. H., and Frazier, N. W. 1985. Habitats and dispersal of the leafhopper vectors of Pierce's disease in the lower San Joaquin Valley. Hilgardia 53:1-32.

33. Purcell, A. H., and Saunder, R. S. 1999. Glassy-winged sharpshooter expected to increase plant disease. Calif. Agric. 53:26-27.

34. Purcell, A. H., Saunder, R. S., Hendson, M., Grebus, M. E., and Henry, M. J. 1999. Causal role of Xylella fastidiosa in Oleander leaf scorch disease. Phytopathology 89:53-58.

35. Raju, B. C., and Gohen, A. C. 1981. Relative sensitivity of selected grapevine cultivars to Pierce's disease bacterial inoculations. Am. J. Enol. Vitic. 32:155-158.

36. Raju, B. C., Gohen, A. C., and Frazier, N. M. 1983. Occurrence of Pierce's disease bacteria in plants and vectors in California. Phytopathology 73:1309-1313.

37. Raju, B. C., Nome, S. F., Docampo, D. M., Gohen, A. C., Nyland, G., and Lowe, S. K. 1980. Alternative hosts of Pierce's disease of grapevines that occur adjacent to grape growing areas in California. Am. J. Enol. Vitic. 31:144-148.
38. Sherald, J. L., and Lei, J. D. 1994. Evaluation of a rapid ELISA test kit for detection of Xylella fastidiosa in landscape trees. Plant Dis. 75:200203.

39. Tangmar, B. B., Yost, R. S., and Uehara, G. 1985. Application of geostatistics to spatial studies of soil properties. Adv. Agron. 38:45-94.

40. Tubajika, K. M., Civerolo, E. L., Bartels, D., and Hashim, J. M. 2002. Spatial patterns of grapevines with Pierce's disease in the lower San Joaquin Valley. (Abstr.) Phytopathology 92(suppl.):S81.

41. Tubajika, K. M., Civerolo, E. L., Puterka, G. J., Bartels, D., Hashim, J. M., and Wittenborn, G. 2002. Epidemiology of Xylella fastidiosa diseases in California. Proc. Pierce's Disease Research Symposium. M. A. Tariq, S. Oswalt, P. Blancoe, and T. Esser, eds. Calif. Dept. Food Agric., Sacramento, CA.

42. Tubajika, K. M., Russin, J. S., and Harrison, S. A. 1999. Analysis of bacterial leaf streak epidemics on winter wheat in Louisiana. Plant Dis. 83:541-548.

43. Wells, J. M., Raju, B. C., Hung, H. Y., Weisberg, W. G., Mandelco-Paul, L., and Brenner, D. J. 1987. Xylella fastidiosa gen. nov., nov.: Gramnegative, xylem-limited, fastidious plant bacteria related to Xanthomonas spp. Int. J. Syst. Bacteriol. 37:136-143.

44. Wu, B. M., van Bruggen, A. H. C., Subbarao, K. V., and Pennings, G. G. H. 2001. Spatial analysis of lettuce downy mildew using geostatistics and geographic information systems. Phytopathology 91:134-142. 